and Ireland on October 15th, 1885. (For summary, see THE LANCET, October 24th, 1885.)

Professor Panas of Paris has lately contributed on the subject, as appears by a letter and a communication from your Paris correspondent, both of which appear in your issue of January 16th. The substance of the letter and correspondence is such, however, as to call for remark. Prominence is given to antisepticism, and the injection is only referred to as a means of introducing the antiseptic within the eye. Not a word is said about the object of the injection being to remove cortex. Professor Panas is too able a surgeon to claim for antiseptics all the advantages put forward. It may be good, and it is a distinct addition to our knowledge that we may without risk inject into the eye a solution of 1 part of biniodide of mercury and 20 parts of 90 per cent. alcohol in 20,000 parts of distilled water. The important matter is, however, that by injection within the eye cortex is easily removed, and that cardinal fact must not be put aside by the secondary question of whether pure water or water containing some antiseptic should be used for injection. I hope soon to have the pleasure and advantage of reading Professor Panas' paper, which I have no doubt, judging from the reputation of the author, is a valuable contribution to the subject; but meantime I think it right to put the question in its proper bearing.

I venture to state my conviction, based on a review of my operative experience of the last fifteen years, that the injection, whether of water pure or medicated with suitable antiseptics, to clear out cortex will be found so advantageous as to secure very quickly its general adoption. The advantages are many: a rapid clearing out of the cortex, the removal of cortex, which friction through the lids, pressure, and scoop could not effect; the removal of cortex concealed by the iris; the clearing of the wound and detection of tags of capsule; the diminution of the percentage of loss of vitreous; the shortening of the duration of the operation; less teasing and irritation; less iritis and irido-choroiditis from remnants left in the eye; less regard to maturity, cataracts being mature for the injection operation when immature for other's. If the section is large enough for easy expulsion of nucleus, there is no fear about getting out cortex whether the section be large or small, or whether aqueous be freely secreted or not. It is applicable, too, to all sorts of incisions large enough to admit easily the scoop, but I think as a general rule iridectomy should be performed.

With all these advantages we should have less panophthalmitis, suppuration of the cornea, slow healing, iritis, and other accidents after operation. Suppuration and other inflammations in eye surgery depend largely on the amount of traumatism and retention of cortex. We must not ignore however, the occasional evil influence of septic germs, and I think ophthalmic surgeons are agreed as to the advisability of using antiseptic precautions and antiseptic treatment as far as practicable.

I have used the irrigation method about thirty times and the injection by the scoop-syringe forty-six times. The fluid used-distilled water previously boiled-has not caused panophthalmitis in a single instance. As to whether it may in the long run be better to use an antiseptic solution than pure water I cannot say, but am open to conviction, and after the testimony to the harmlessness of certain antiseptics borne by Dr. Wicherkiewicz and Professor Panas I am ready to try.

The immediate occlusion of the wound by an antiseptic gelatine plaster, proposed and practised by Dr. Galezowski, should be very advantageous. Besides preventing for the time-the most critical time-the introduction of germs from a diseased conjunctiva or lacrymal sac, it restores the anterior chamber, and thus allows the parts involved in the operation to come more quickly into natural relation. With the restoration of the chamber, the capsule is separated from the corneal wound, the capsule, iris, and cornea are no longer in apposition, and internal congestion from the diminution of the contents of the eyeball prevented or lessened. If it be found effectual in promoting early healing of the wound, $\Gamma$ anticipate less adhesions of capsule and iris to wound and less internal inflammation.

Whilst ophthalmic surgeons should spare no effort to banish panophthalmitis, it is well to bear in mind that the losses from that inflammation (from 1 to 2 per cent.) are very much less than from iritis and irido-choroiditis, about which we do not write or talk so much.--Yours truly,

Belfast, Jan. 18th, 1886.

\section{SOUTH AFRICA AS A RESIDENCE FOR CONSUMPTIVES.}

\section{To the Editor of THF LANCET.}

SIR,-I have just received the following letter from an old friend who left England seven years ago with symptoms of advanced phthisis in both lungs, even to a greater extent than he himself describes; and as it contains some most instructive information for any patients who are suffering from phthisis and wish to go abroad, I have ventured to ask you to publish it in extenso, omitting only the personal details. Few doctors or patients appreciate that the up-country districts of South Africa can be so easily reached and have such good accommodation. I might add that Dr. Woolby who was recently drowned while bathing, also derived much benefit from living in a similar climate and following practically a similar plan of life, at Engcobo, in another inland district of South Africa.-Yours faithfully,

George-street, Hanover-square, Feb. 9th, 1886. John CuRnow, M.D.

\section{The Convalescent Home, West Barkly, Griqualand West,} South Africa, Nov. 8th, 1885 .

MY DEAR DR. CURNow,-You will probably be surprised to hear from your old demonstrator and prosector after seven years' of silence. You must think, unless you have come across my name, once or twice mentioned in THE LANCET during the last few years, that I have long ago joined the "great majority." Nevertheless, you will be glad to hear, I $\mathrm{know}$, that I am in the land of the living yet, and, what is more, that I am in the enjoyment of very good-l may say, robust-health. You may remember that when I last had the pleasure of seeing you in London, when I took my final departure for this country, I was particularly ill-a cavity in my right lung, consolidation of the top of the other, combined with profuse and almost daily hæmoptysis, had reduced me to the most miserable condition. I came out here. During the voyage I was more or less ill. No hæmoptysis, but the cough and my general condition were bad. I stayed in Capetown about three weeks; it was cold and wet there, and it did not agree with me. I started to get higher up the country, and arrived in Kimberley, the capital of the diamond fields, 600 miles in the interior. There I commenced practice, and soon made a decent living. Those were good days then: few doctors and big fees. I was there six months, but the dust of the mines in those days, combined with the worry of a general practice in a large town, was not altogether suited to me. I was anything but strong. At the end of six months, my predecessor in Barkly having made what he considered a small " pile," retired and offered his practice to me. I took it and have been here ever since, more or less contented with my lot; more contented than otherwise, for the out-door country life in a splendid climate (for lungs) has made me a different individual with regard to health. I can now stand "knocking about" with most men. I can do fifty and sixty miles, and have done them frequently in a day, in the saddle. I am the Government or district surgeon of the Barkly division, about the size of a small English county, a justice of the peace for the division, and the only private practitioner. There are over twenty medical men in Kimberley, twenty-five miles off, if I should require a consultation. The town of Barkly, containing about 500 inhabitants, white and coloured, is situated on a high bank overlooking the Vaal river. The river, next to the Orange, the largest in South Africa, is a very pretty one, the banks being well lined with trees. It reminds me in some parts of its course of the Wye at home. There is plenty of fishing, bathing, boating, and shooting to be had in and on it. Most of the hills or "Koptjes" adjoining its banks contain diamonds, some of them of the most beautiful water. There is still a considerable number of diggers digging for diamonds on the Vaal, and in it when the water is low. But unless luck attends one, digging-life on the Vaal is a rather precarious existence, The climate is dry, too dry for most things but lungs. November, December, and January are very hot months$-96^{\circ}-98^{\circ}$ in the shade while the sun is up; but amends is made even then by the evenings and mornings being fresh and cool. After January it begins to get cooler in the daytime each month. May, June, and July are delightful months; get frost at night; can be out all night and day. 
August, September, and October are warmer but very pleasant months. But whatever the month be, the nights are cool after the hottest day, and permit of sleep. Winter nights are cold enough to make one enjoy a fire, and a big one too. We are 5000 feet above the sea. Both this district and Kimberley aoound with people who tell us that tney came out for "their lungs," al though to look at them you would seldom guess it. They tell pitiable tales of their sufferings at home, and the helpless state in which they arrived here. They tell us that they have been so many years in the country, and that they have quite recovered. I know bankers, merchants, diggers, policemen, and all sorts and conditions of men, now well in health and doing more or less well in their businesses, who came out consumptive. I have often thought of writing to you to try and point out the advantages this part of South Africa offers to consumptives. Up to the present time, however, the difficulty of getting here was great. It was expensive, tedious, and trying to a sick person. Now this is altered. After a passage in a magnificent mail boat to Capetown, the invalid can get into a Pullman car and travel 600 miles into a splendid station in Kimberley in thirty-six hours. A coach and four will bring him down to Barkly in three hours, along a good road, if he wishes. Very different thing to the days when poor Harry Leach wrote of travelling in these parts, in an old wine-case on wheels, called a post-cart. I think the shaking he got during his hasty travels in these parts did mueh to shorten his days. When I came up from Capetown to Kimberley in 1878 it took me twenty-one days in a mule waggon, and a very rough time it was, in a broiling sun, through the hot sand of the desert Karroo. Now the mail trains from Capetown and Port Elizabeth rush daily into Kimberley. In 1878 the people of Kimberley lived in tin and canvas houses or huts, horribly hot and uncomfortable. Vegetables, fruit, butter, sc., were luxuries we seldom came across. I have known the humble cabbages sell for $10 s .6 d$. a-piece on the market, other vegetables in proportion. The late Anthony Trollope, who visited Kimberley in 1878, shook the dust from his feet and departed a sadder if a wiser man. He gave a sad description of us in his next published work. Now all things are altered. A waterworks company pumps an unlimited supply of water from the Vaal River for the use of the Kimberley people; trees and gardens are springing up all round; unlimited fruit and vegetables are brought up daily by train; people have built large and commodious houses; the town is lit by electric light; we boast of a club that costs the members some $£ 25,000$ - by far the best club in the colony. In short, Kimberley is not such a bad place to live in now, but it is not exactly a good place for an invalid with "lungs"; there is still too much dust from the mines to suit irritable respiratory organs. Barkly, on the other hand, is free from dust ; it is within easy distance (twenty-five miles) of the railway station, and is blessed with a fine river, which affords a means of much recreation. Further, it is very Sealthy in a fever and zymotic disease point of view. My business therein is "nil." Children only trouble me when they come into the world, when they cut their teeth, and when they do little things they ought not to do and suffer the conseguences, riding papa's untamed steed, and getting "bucked off" with broken bones for example, or teasing the patient, and getting a dig in the ribs for their pains, \&c. In Kimberley, on the other hand, the sanitary arrangements used to be shocking, consequently there was much fever. There was no railway to the sea then. Many of the fever people came down here; now most of the patients go to the sea-coast to " pick up." I live in a by no means uncomfortable house: it is a Government building, built of stone. Cool in summer and warm in winter, with good large lofty rooms, it stands about fifty yards from the river and about a quarter of a mile out of the village of West Barkly. There are eight or ten acres of unoccupied ground all round the place. I keep a sort of cross between a hospital and a convalescent home in it, that is, $\mathrm{I}$ have to take in acute cases, accidents, \&c., from among the white population of the district, while at the same time I take in as many convalescents as possible. Last year we took in sixty-nine during the year. The Government give a grant towards maintaining two free patients; the rest are paying patients, who pay 12s. $6 d$. per diem, exclusive of wines and extras. If the patient is not in a hopeless state when he arrives here, he could almost be guaranteed a cure by simple residence, without drugs or oil or confinement; simply by fresh dry air night and day. A patient should stay here at least twelve months, longer if possible. It took me two years to quite get rid of my cough and every vestige of expectoration, but twelve months made me quite a different man. A male patient from twelve to fourteen years of age upwards would have the best chance of getting rapidly well here. I am sure riding and driving are of invaluable assistance in aiding the damaged lungs to recover. We get an English mail and papers every week, and can obtain any amount of books from the Kimberley Public Library. There is shooting for those who can shoot. There is good coursing after buck and hare. I get good fun coursing during the winter. With regard to children, if strong enough it could be arranged for them to go on with their education for a few hours every day. There is an English church and rector (wife and family) here; a civil commissioner and magistrate, and a number of officials. Ladies from England would probably find it rather dull, as there would not be the same facilities for occupying their spare time as there are for men. The ladies here are, however, pretty active at lawn tennis, and manage generally to amuse themselves without much complaint. Patients, as a rule, have not been sent far enough up country by doctors at home. Our old family doctor in England, hearing that I was still alive, some years ago sent four patients out in consumption. They all stayed within 200 miles of the coast, where the climate is given to much rain, and consequently the air is moist, hot, and enervating; they all died. If they had come to this almost rainless part of the world I believe they might all have got better. Saloon fare to Capetown, $£ 35$; railway fare to Kimberley, first-class, $£ 66 s$. I am afraid I have bored you with this disjointed letter. I commenced it in November last, and came across it again to-day, Jan. 10th, 1886. I will only point out in a condensed form what is hardly yet known to physicians in London-viz: 1. That consumptive patients can now travel up to the driest part of the Cape Colony in the most comfortable manner. 2. That, having arrived there, they can obtain fairly comfortable and well-appointed quarters to reside in.-Believe me, ever yours sincerely,
Dr. John Curnow, London.
W. R. HARRHY, M.R.C.S.

\section{THE TREATMENT OF PERTUSSIS.}

\section{To the Editor of THE LANCET.}

Sin,-At the time of writing my letter about the treatment of whooping-cough, I was not aware that carbolic acid had ever been given internally for that complaint, although I was cognisant of the fact that it had been frequently used as a remedy by inhalation; but this method, although of some use, I had never considered capable of neutralising or destroying the exciting cause of the disease, which, in my opinion, does not originate and multiply in the respiratory tract, in spite of the symptoms being mainly manifested there, but at some point in the prime vice. That this is a fact is fully proved by the result of the treatment adopted. I can account for not having seen Mr. Harries' communication of July 13th, 1878 , as at that time I was travelling in the Pacific Ocean (quite a misnomer, by the bye), and my opportunities of perusing THE LANCET, I regret to say, were few and far between. I would like to add that the more I see of the effects of different kinds of treatment in disease, the greater I am impressed with the importance of prescribing antiseptics, especially in the zymotic varieties; for instance, without laying any claim to originality, I always prescribe eucalyptus globulus in rötheln, chlorine in scarlatina and diphtheria, and carbolic acid in typhoid, with the most satisfactory results. I am, Sir, yours obediently Bournemouth, Jan. 23rd, 1886.

F. W. CORY.

\section{To the Editor of THE LANCET.}

SIR,--In the year 1883 I wrote an essay, as a competitor for the Fothergillian Gold Medal of the Medical Society of London, on the Pathology and Treatment of Whoopingcough, in which $I$ gare the results of my investigations and study of this disease, which $I$ had been pursuing for two years previously. They were, briefly, that it is a specific disease, affecting the blood, but having the bronchial mucous membrane as its chief seat, the specific organism developing there, and infecting the blood from thence. In this view I was supported by Mr. T. Dolan. In 